NOTICE: This is the author's version of a work that was accepted for publication in Chemical Engineering Journal. Changes resulting from the publishing process, such as peer review, editing, corrections, structural formatting and other quality control mechanisms may not be reflected in this document. Changes may have been made to this work since it was submitted for publication. A definitive version was subsequently published Chemical Engineering Journal, Volume 222, 15 April 2013, Pages 108-119. http://dx.doi.org/10.1016/j.cej.2013.02.029 


\title{
Batch and column studies of phosphate and nitrate adsorption on waste solids containing boron impurity
}

\author{
Asim Olgun ${ }^{\mathrm{a},}$, Necip Atar ${ }^{\mathrm{a}}$, and Shaobin Wang ${ }^{\mathrm{b}, *}$ \\ ${ }^{\mathrm{a}}$ Department of Chemistry, University of Dumlupinar, Kutahya, Turkey \\ ${ }^{b}$ Department of Chemical Engineering, Curtin University, GPO Box U1987, Perth, WA 6845, \\ Australia
}

\begin{abstract}
In the present study, we investigated the removal characteristics of phosphate and nitrate through adsorption on boron waste (BW) and heat treated boron waste (BW400) under batch equilibrium and column flow conditions. The effects of $\mathrm{pH}$, contact time, initial solution concentration, and temperature on the uptake of both anions by the adsorbents in batch operation were examined. The equilibrium data were fitted to different types of adsorption isotherms. Langmuir adsorption model showed the best fit to the experimental adsorption data. The data were further analyzed on the basis of the Lagergren first order, pseudo-second-order and intraparticle diffusion kinetic models. The maximum adsorption capacities of heat treated BW for nitrate and phosphate were approximately 63.2 and $52.5 \mathrm{mg} \cdot \mathrm{g}^{-1}$, respectively, which shows higher maximum capacity for phosphate and a similar capacity for nitrate in comparison with other adsorbents used. Breakthrough curves obtained from fixed-bed column tests showed that column adsorption capacities provided strong evidence of the potential of BW400 for the technological applications of phosphate and nitrate removal from aqueous solutions.
\end{abstract}

Key words: Phosphate, nitrate, adsorption, solid waste, water treatment

\footnotetext{
* Corresponding author.

E-mail address: shaobin.wang@curtin.edu.au (S. Wang); aolgun@dumlupinar.edu.tr (A. Olgun)
} 


\section{Introduction}

Water pollution due to excessive presence of nitrogen and phosphorus species has become a serious problem worldwide in recent years. Agricultural, industrial, households uses and many other human activities are the major sources of phosphates and nitrates in natural bodies of water [1]. Phosphate and nitrate can contribute significantly to eutrophication in the aquatic environment. Eutrophication comprises the abundance of aquatic plants, growth of algae, and depletion of dissolved oxygen in water [2]. Furthermore, high nitrate concentration in drinking water can lead a potential risk to animal and human health. Excessive level of nitrate in drinking water can cause acute poisoning in cattle [3], a blue baby disease in newborn infants [4, 5], and the potential formation of carcinogenic nitrosamines [6].

Several physicochemical and biological processes have been used for the removal of dissolved heavy metals, dyes, phosphate and nitrate in water and wastewaters [7-15]. Among them adsorption method has become a popular method since it allows simple and economical operation resulting in less sludge production. A number of materials including carbon-based sorbents [16-17], biosorbents [1824], natural sorbents [25-30], miscellaneous adsorbents [31-35], agricultural wastes [36, 39], and industrial wastes $[40,41]$ have been tested for the removal of nitrate and phosphate from waste waters.

In recent years, considerable experimental progresses have been made in the use of wastes containing boron impurity for the removal of heavy metals [42-44] and dyes [45-48] from aqueous solutions. Boron waste (BW) is a waste residue formed during boron enrichment process in different boron plants in Turkey. Chemical composition of BW changes with respect to the type of the boron ore sources. BW is mainly composed of ulexite, zeolite, colemanite, and some clays. Due to chemical and mineralogical species present in the $\mathrm{BW}$, this solid waste is an excellent low-cost adsorbent for the removal of pollutants from water.

The primary objective of this work is to develop a process for removal of phosphate and nitrate from aqueous solution using adsorption based technology. For this purpose, adsorption characteristics of these anions on BW and heat treated BWs were systematically investigated under batch equilibrium and column flow conditions. The effects of various operating conditions, namely, $\mathrm{pH}$ of solution, initial concentration of anions, contact time, and temperature, were investigated. The experimental data were analyzed on the basis of the Langmuir, Freundlich, and Dubinin-Raduskovich adsorption equations. Further, the experimental data were fitted to the Lagergren first-order, pseudo-second order and intra-particle diffusions models. Column adsorption data were used to obtain breakthrough adsorption capacity of adsorbents for nitrate and phosphate ions.

\section{Materials and methods}

\subsection{Materials}

Analytic grade $\mathrm{KNO}_{3}$ and $\mathrm{KH}_{2} \mathrm{PO}_{4}$ (Merck, Germany) were used in all experiments. A stock solution of nitrate and phosphate $\left(1000 \mathrm{mg} \cdot \mathrm{L}^{-1}\right)$ were prepared by dissolving required amount of 
chemicals in distilled water. Solutions at various concentrations were obtained by diluting the stock solution with distilled water to the desired concentration. The waste material (BW) was obtained from Etibor (Bigadiç Balıkesir, Turkey) and dried at $90{ }^{\circ} \mathrm{C}$ for two hours. The BW was prepared by grinding it in a laboratory type ball-mill. It was then screened through a 63 mess sieve. Chemical components of $\mathrm{BW}$ based on dry weight mainly are: $\mathrm{Na}_{2} \mathrm{O}$ (7.52\%), $\mathrm{B}_{2} \mathrm{O}_{3}$ (13.37\%), $\mathrm{CaO}$ (17.52\%), $\mathrm{MgO}$ (10.32\%), $\mathrm{SO}_{3}(14.20 \%)$, and $\mathrm{SiO}_{2}(15.50 \%)$ [42]. This sample was referred to as $\mathrm{BW}$. In order to examine the effect of heat treatment on the adsorption capacity of BW, the sample was heat treated at varying temperatures $\left(300,400,500\right.$, and $\left.600^{\circ} \mathrm{C}\right)$ for $4 \mathrm{~h}$.

\subsection{Characterization of the adsorbents}

Zeta potential measurements of BW and heat treated BWs were conducted using a Zeta meter (Zeta meter $3.0+542$, USA) over a broad range of $\mathrm{pH}$ (3 to 9). A known amount of BW was suspended in $50 \mathrm{~mL}$ of distilled water, and the solution $\mathrm{pH}$ was adjusted between 3.0 and 9.0. After $\mathrm{pH}$ adjustment, the mixtures were equilibrated with a magnetic stirrer for $20 \mathrm{~min}$, and the Zeta potential was measured. The BET surface areas of original BW and heat treated BWs were determined by the nitrogen adsorption isotherm technique on an automatic BET surface area analyzer (Quantachrome, NOVA 2200, USA).

\subsection{Batch adsorption studies}

The adsorption capability of $\mathrm{BW}$ and BW400 toward nitrate and phosphate anions was investigated separately using aqueous solutions of $\mathrm{KNO}_{3}$ and $\mathrm{KH}_{2} \mathrm{PO}_{4}$. Adsorption was performed batch-wise in Erlenmeyer flasks on a temperature regulated platform stirrer under the following conditions: temperature $25-55^{\circ} \mathrm{C}$, adsorbent dosage $2 \mathrm{~g} \cdot \mathrm{L}^{-1}, \mathrm{pH} 3-8$, an initial concentration 50- 120 $\mathrm{mg} \cdot \mathrm{L}^{-1}$ and $50-140 \mathrm{mg} \cdot \mathrm{L}^{-1}$ for phosphate and nitrate ions, respectively. The $\mathrm{pH}$ of the solutions was adjusted by adding either $0.1 \mathrm{M} \mathrm{HCl}$ or $0.1 \mathrm{M} \mathrm{NaOH}$. The adsorbent and anion suspensions were continuously agitated with a speed of $200 \mathrm{rpm}$ for $90 \mathrm{~min}$. Following the exposure of adsorbents to phosphate and nitrate anions, the samples were collected by centrifugation at $5000 \mathrm{rpm}$ for $15 \mathrm{~min}$.

Phosphate ion concentration in residual solutions was determined by the formation of ammonia phosphomolybdate and the subsequent reduction with ascorbic acid followed by spectrophotometric measurement at $880 \mathrm{~nm}$ with a spectronic 20 Genesis model spectrophotometer. Nitrate ion concentration in the solution was analyzed by NitroVER5 powder-pillow test kids. The amount of anions adsorbed per unit weight of adsorbent $\left(\mathrm{q}_{\mathrm{e}}\right)$ was calculated using the following equation:

$$
q_{e}=\frac{\left(C_{i}-C_{e}\right) V}{m}
$$


where $C_{i}$ and $C_{e}$ represent initial and equilibrium concentrations of ions in $\mathrm{mg} \cdot \mathrm{L}^{-1}$, respectively, $V$ is the volume of solution in liters $(\mathrm{L})$; and $\mathrm{m}$ is the mass of the adsorbent in grams $(\mathrm{g})$.

\subsection{Column experiments}

Fixed-bed column studies were performed using a laboratory scale glass column with an internal diameter of $1 \mathrm{~cm}$ and a length of $12 \mathrm{~cm}$. A stainless sieve was attached at the bottom of column with a layer of glass wool. A known quantity of anion solution was fed in upwards through the column. The column was operated at three different flow rates ranging $0.5-1.5 \mathrm{~mL} \cdot \mathrm{min}^{-1}$ for a solution concentration of $100 \mathrm{mg} \cdot \mathrm{L}^{-1}$, a bed height of $12 \mathrm{~cm}, \mathrm{pH} \mathrm{3}$, and $25{ }^{\circ} \mathrm{C}$. The effect of adsorbate concentration on the adsorption capacity of adsorbents was studied using initial anion concentrations ranging from 100 to $300 \mathrm{mg} \cdot \mathrm{L}^{-1}$. In addition, the bed height $(6,9$, and $12 \mathrm{~cm})$ was studied at an initial anion concentration of $100 \mathrm{mg} \cdot \mathrm{L}^{-1}$. Effluent samples were collected at the outlet of the column at regular time intervals and analyzed for anion concentration. The breakthrough curves were obtained by plotting the ratio $\left(\mathrm{C} / \mathrm{C}_{0}\right)$ of anion concentration $(\mathrm{C})$ at time $\mathrm{t}$ to initial concentration $\left(\mathrm{C}_{0}\right)$ versus time $(\mathrm{t})$.

\section{Results and discussions}

\subsection{Batch adsorption tests}

\subsubsection{Effect of initial solution $\mathrm{pH}$}

The effect of initial solution $\mathrm{pH}$ on nitrate and phosphate removal by two adsorbents is illustrated in Fig. 1. Adsorption capacity, $\mathrm{q}_{\mathrm{e}}$, was analyzed over a $\mathrm{pH}$ range of 3-9. It is seen that adsorption of anions were considerably influenced by the $\mathrm{pH}$ of solutions. There was an increase in the adsorption capacity of adsorbents with decreasing $\mathrm{pH}$ from 8 to 3 for both anions and the maximum adsorption capacity was observed at $\mathrm{pH} 3$. The variation of adsorption with $\mathrm{pH}$ can be explained by the electrostatic interaction between the adsorbent and adsorbate. As seen in Fig. 2, zeta potentials of BW400 are higher than those of BW at different pHs, giving zero charge of BW and BW400 at 4.1 and 5.8, respectively. The adsorbents are positively charged at lower $\mathrm{pH}$ and positive charge density on the adsorbents favors the adsorption of nitrate and phosphate anions. Increasing $\mathrm{pH}$ of the solution results in a negative zeta potential that causes increased electrostatic repulsion between negatively charged surface and negatively charged ions in the solutions.

\section{[Insert Fig.1]}

\section{[Insert Fig.2]}

The comparison of the adsorption capacities of adsorbents showed that BW400 was more effective for nitrate and phosphate adsorption than BW in the $\mathrm{pH}$ ranges studied. The difference in the adsorption capacity of adsorbents can be explained with the surface charge on the adsorbents (Fig. 2).

\section{[Insert Fig.3]}




\subsubsection{Heat treatment results}

The effect of heat treatment on the anion removal of BW is seen in Fig. 4. It is apparent that phosphate and nitrate removal capacity of BW increased with increasing temperature up to $400{ }^{\circ} \mathrm{C}$. The samples heated beyond $400{ }^{\circ} \mathrm{C}$ showed lower phosphate and nitrate removal capacity than those heated at 400 ${ }^{\circ} \mathrm{C}$. These results can be mainly attributed to the surface area of the BW. As seen from Fig. 3 that the surface area of BW increases with increasing temperature up to $400{ }^{\circ} \mathrm{C}$. The increase in the surface area is resulted from the structural changes that occur during heating. The XRD patterns of BW and calcined BW showed that the major phases of BW are ulexite, calcite, and colemanite, with minor dolomite, and zeolite. After heating, the peak intensities for ulexite significantly decrease [46]. Heat treatment results in dehydration and dehydroxylation reactions in ulexite. Meanwhile the gradual removal of water increases the porosity up to $400{ }^{\circ} \mathrm{C}$. Thus, increase in porosity of BW particles leads to an increase in surface area. The higher surface area produced higher adsorption capacity of BW. At temperature higher than $400{ }^{\circ} \mathrm{C}$, it is probable that the sintering reactions at grain boundary result in breakdown of pores thereby reducing the specific surface area.

\section{[Insert Fig.4]}

\subsubsection{Effects of contact time, temperature, and initial ion concentration}

The effect of initial anion concentration on uptake capacity of BW and BW400 was studied at pH 3.0 and $25^{\circ} \mathrm{C}$. The results showed that the anion uptake capacity of BW increased from 8.56 and 9.08 $\mathrm{mg} \cdot \mathrm{g}^{-1}$ at $10 \mathrm{mg} \cdot \mathrm{L}^{-1}$ initial concentration to $28.65 \mathrm{mg} \cdot \mathrm{g}^{-1}$ and $43.55 \mathrm{mg} \cdot \mathrm{g}^{-1}$ at initial phosphate and nitrate concentrations of $120 \mathrm{mg} . \mathrm{L}^{-1}$ and $140 \mathrm{mg} . \mathrm{L}^{-1}$, respectively. The adsorption capacity of BW400 increased to 52.38 and $63.15 \mathrm{mg} \cdot \mathrm{g}^{-1}$. This may be attributed to the number of available active adsorption sites and solution concentration.

In order to establish the equilibration time for maximum adsorption of nitrate and phosphate and to know the kinetics of the adsorption process, the adsorption of anions on BW and BW400 were studied as a function of contact time. Figs. 5 and 6 display the effect of contact time on the adsorption capacity of BW400 at different temperatures. The adsorption of phosphate and nitrate ions was rapid in the first stage, followed by a slow stage. The phosphate uptake nearly reached equilibrium in 90 min on BW (Figures not given). However, equilibrium was established in $75 \mathrm{~min}$ on BW400 indicating positive contribution of structural changes that occur in adsorbent during heating to the extent of adsorption. In phosphate adsorption studies, $90 \mathrm{~min}$ and $75 \mathrm{~min}$ were chosen as the optimum contact time for BW and BW400. The uptake of nitrate reached equilibrium in 90 min on both 
adsorbents. The loading capacity of the adsorbents significantly increased with an increase in the temperature from 25 to $55^{\circ} \mathrm{C}$.

\section{[Insert Fig.5]}

\section{[Insert Fig.6]}

\subsubsection{Adsorption kinetics}

The kinetics of adsorption of phosphate and nitrate on various materials has been studied using various kinetic equations. The best prevailing equation is the Lagergren pseudo-first order model [49]. It can be written as

$\log \left(q_{e}-q_{t}\right)=\log q_{e}-\left(k_{1} / 2.303\right) t$

where $q_{e}$ and $q_{t}$ are the amounts of anions adsorbed per unit mass of the adsorbent materials $\left(\mathrm{mg} \cdot \mathrm{g}^{-1}\right)$ at equilibrium time and time $\mathrm{t}$, respectively, while $k_{l}$ is the pseudo-first order rate constant $\left(\mathrm{min}^{-1}\right)$. The integral form of the pseudo-second-order model is given by the following equation [50];

$\frac{t}{q_{t}}=\frac{1}{k_{2} q_{2}^{2}}+\frac{1}{q_{2}} t$

where $q_{2}$ is the maximum adsorption capacity $\left(\mathrm{mg}^{-1} \mathrm{~g}^{-1}\right) ; k_{2}$ is the rate constant of the pseudo-second order equation $\left(\mathrm{g} \cdot \mathrm{mg}^{-1} \cdot \mathrm{min}^{-1}\right) ; q_{t}$ is the amount of anion adsorbed per unit mass of the adsorbent $\left(\mathrm{mg} \cdot \mathrm{g}^{-1}\right)$.

The experimental data were fitted to both the first- and second-order adsorption models. Kinetic parameters were calculated from the straight line plots of the first- and second-order equations. The kinetic constants and correlation coefficients of the pseudo-first-order and the pseudo-second-order models are given in Table 1. Although, calculated $\mathrm{q}_{\mathrm{e}}$ values for the pseudo-first-order models are closer to the experimental $\mathrm{q}_{\mathrm{e}}$ values, the pseudo-second-order rate model has produced higher correlation coefficients $\left(\mathrm{R}^{2} \approx 0.99\right)$ compared to the correlation coefficient $\left(\mathrm{R}^{2} \approx 0.85-0.99\right)$ of the pseudo-first-order rate model. All the linear correlations coefficients of the second-order model were found to be statistically significant, as it is evident from the $R^{2}$ values, indicating the applicability of this kinetic equation to the adsorption of both phosphate and nitrate anions. The pseudo-second-order rate constants values calculated for $\mathrm{BW}$ were found to be higher than that of heat treated $\mathrm{BW}$ for nitrate ion. The results show that the heat treatment enhances the adsorption rate by increasing both the amount of nitrate and phosphate adsorbed per unit mass of the adsorbent at equilibrium time. This enhancement may possibly be attributed to the removal of the water and hydroxyl groups from adsorbent during heat treatment resulting in the opening of the pores and increased BET surface area of the BW.

\section{[Insert Table 1]}


Previous studies on the kinetic behaviors of microporous sorbents showed that intraparticle surface diffusion may be important to the adsorption process [41, 42]. It is well known that adsorption is a multi-step process in which adsorbate species are most probably transported from the bulk of the solution to the solid phase through an intra particle/transport process. In this study, the possibility of the intra-particle diffusion rate affecting adsorption was also examined using the intra-particle diffusion model as [51].

$q_{t}=k_{p} \sqrt{t}+C$

where $\mathrm{q}_{\mathrm{t}}$ is the amount of anions adsorbed at time $\mathrm{t}$; $\mathrm{C}$ is the intercept and $\mathrm{k}_{\mathrm{p}}$ is the intra-particle diffusion rate constant $\left(\mathrm{mg} \cdot \mathrm{g}^{-1} \mathrm{~min}^{-0.5}\right)$. The $\mathrm{k}_{\mathrm{p}}$ values for both nitrate and phosphate adsorption on BW and BW400 were estimated by linear regression analysis and found in the range of 1.68 and 3.71. It was found from the plots of $\mathrm{q}_{\mathrm{t}}$ versus $\mathrm{t}^{1 / 2}$ that the plots show multi-linearity for two anions implying existence of more than one kinetic stage in adsorption process. The estimated values of $\mathrm{k}_{\mathrm{p}}$ were found higher for heat treated BW than the original material. The results show that heat treatment has positive contribution to the intra-particle diffusion rate. As seen in Table 1 the intercept values for original BW are lower than that of the BW400. This may be attributed to the decreased boundary layer effect and higher BET surface area of the heat treated BW.

\subsubsection{Adsorption isotherms}

In order to optimize the design of the adsorption system for the removal of phosphate and nitrate ions from the solution, it is important to establish a correlation for the equilibrium curves obtained from the experimental studies. Therefore, Langmuir and Freundlich isotherm models were used. The Langmuir isotherm [52] takes the form:

$q_{e}=\frac{q_{\max } K_{L} C_{e}}{1+K_{L} C_{e}}$

where $q_{e}$ is the adsorbed amount of solute in $\mathrm{mg} \cdot \mathrm{g}^{-1}, C_{e}$ is the equilibrium concentration of the liquid solution $\left(\mathrm{mg} \cdot \mathrm{L}^{-1}\right), q_{\max }$ is the monolayer capacity of the adsorbent $\left(\mathrm{mg} \cdot \mathrm{g}^{-1}\right)$ and $K_{L}$ is the Langmuir constant related to the free energy of adsorption. The values of the parameters were evaluated from the linear plot of $1 / \mathrm{q}_{\mathrm{e}}$ versus $1 / \mathrm{C}_{\mathrm{e}}$. The Freundlich adsorption isotherm [53] is expressed as:

$q_{e}=K_{F} C_{e}^{1 / n}$

where $K_{F}$ and $\mathrm{n}$ are the Freundlich constants related to adsorption capacity and intensity, respectively, The values of constants were obtained from the linear plot of $\log \mathrm{q}_{\mathrm{e}}$ and $\log \mathrm{C}_{\mathrm{e}}$. Values of the constants of the two models along with the regression coefficients $\left(\mathrm{R}^{2}\right)$ are listed in Table 2. The results indicate that both adsorption models fit the experimental data well. However, the Langmuir equation gives a 
relatively better representation compared with Freundlich model. Fig.7 shows Langmuir isotherm for adsorption of anions on BW and BW400. As seen from the plot and Table 2, adsorption properties of BW were enhanced by heat treatment. Comparison of the maximum adsorption anion uptake capacity of BW400 with the other adsorbents as reported in literature is given in Table 3. The BW400 prepared in this study can be considered as the alternative materials for nitrate and phosphate removal in aqueous solution.

\section{[Insert Fig.7]}

\section{[Insert Table 2]}

\section{[Insert Table 3]}

The equilibrium data were also subjected to the Dubinin-Raduskovich adsorption isotherm model (D$\mathrm{R}$ isotherm) [54] to determine the nature of sorption process as physical or chemical adsorption. The non-linear form of the isotherm equation is given as:

$q_{e}=Q_{m} \exp \left(-k\left[R T \ln \left(1+\frac{1}{C_{e}}\right)^{2}\right]\right)=Q_{m} \exp \left(-k \varepsilon^{2}\right)$

where $q_{m}$ is the maximum amount of the ion that can be sorbed onto unit weight of sorbent $\left(\mathrm{mg} \cdot \mathrm{g}^{-1}\right), \varepsilon$ is the Polanyi potential, which is equal to $R T \ln \left(1+1 / C_{e}\right)$, where $R$ and $T$ are the universal gas constant $\left(\mathrm{kJ} \mathrm{mol}^{-1} \mathrm{~K}^{-1}\right)$ and the absolute temperature $(\beta)$, respectively. $\beta$ is related to the mean free energy of sorption per mole (E) of the anion transferred to the surface of the adsorbed from the solution when it is transferred to the surface of the solid from the solution and $\mathrm{E}$ can be formulated as:

$$
E=\frac{1}{\sqrt{2 \beta}}
$$

The Dubinin-Radushkevich isotherm parameters are shown in Table 2. The E values obtained in this study are greater than $8 \mathrm{~kJ} \mathrm{~mol}^{-1}$, indicating possibility of ion-exchange mechanism. Consequently, the results showed that Langmuir isotherm model is better fit than Freundlich, and D-R isotherm models tested with respect to the correlation coefficients, and other parameters determined for these three isotherms models.

\subsubsection{Thermodynamic studies}

Thermodynamic parameters shed valuable insight into feasibility and spontaneity nature of the adsorption process. Thermodynamic parameters, namely, the standard Gibbs free energy change $\left(\Delta \mathrm{G}^{\theta}\right)$, standard entropy change $\left(\Delta \mathrm{S}^{\theta}\right)$, and standard enthalpy change $\left(\Delta \mathrm{H}^{\theta}\right)$ were obtained using equilibrium constants at different temperatures $\left(25-55^{\circ} \mathrm{C}\right)$. The adsorption equilibrium constant $\left(\mathrm{K}_{\mathrm{c}}\right)$ is expressed as: 
$K_{c}=\frac{C_{a d}}{C_{e q}}$

$\mathrm{C}_{\mathrm{ad}}$ is the amount of ions (mol) adsorbed on the adsorbent per liter (L) of the solution at equilibrium, and $\mathrm{C}_{\mathrm{eq}}$ is the equilibrium concentration $\left(\mathrm{mg} \cdot \mathrm{L}^{-1}\right)$ of the anions in the solution. The standard Gibbs energy change of the adsorption is given as:

$\Delta G^{\theta}=-R T \ln K_{c}$

Other thermodynamic parameters were determined from the slope and intercept of the linear plot (figure not given) in $\mathrm{K}_{\mathrm{c}}$ versus $1 / \mathrm{T}$, and using following equation:

$\ln K_{c}=-\frac{\Delta H^{\theta}}{R T}+\frac{\Delta S^{\theta}}{R}$

The thermodynamic parameters are given in Table 4. At low temperatures, the negative values of $\Delta \mathrm{G}^{\theta}$ indicate spontaneous nature of nitrate and phosphate adsorption on BW and BW400. Increasing temperature results in a positive change in $\Delta \mathrm{G}^{\theta}$ values obtained for BW. This result may be attributed to the energy gained from the external source at high temperatures. The negative value of the enthalpy change indicates that the adsorption is exothermic in nature. The negative values of $\Delta S^{\theta}$ show decreased randomness at the solid/solution interface during the adsorption of anions on the adsorbent and some structural changes in the heat treated adsorbent.

\section{[Insert Table 4]}

\subsection{Column adsorption studies}

\subsubsection{Effect of flow rate}

Fig.8 shows breakthrough curves at three initial flow rates for phosphate/BW400 and nitrate/BW400 at a fixed-bed height of $12 \mathrm{~cm}$ and initial concentration of $100 \mathrm{mg} \cdot \mathrm{L}^{-1}$. The shape of the breakthrough curves indicates the internal resistance within the column and the relative effects of mass transfer parameters throughout the operating condition. It was observed that the breakthrough curve of lower flow rate rises steeply near exhaustion point indicating a larger mass transfer zone and a longer service time for the column. The breakthrough curves for both anions were sharper for higher flow rates. This was likely due to the facts that anions do not have enough time to contact with surface sites a high rate of loading, which results in a lower adsorption capacity. Based on the breakthrough curves, at $0.5 \mathrm{~mL} \cdot \mathrm{min}^{-1}$ loading rate more efficient anion uptake occurred than other loading rates tested for both anions (Table 5). Results also indicated that the shape of breakthrough curves (Figures not given) for nitrate/BW and phosphate/BW showed a similar trend as those of phosphate/BW400 and nitrate/BW400 systems. However, adsorption capacities of BW400 for both anions were found to be higher than those of BW at all loading rates (Table 5).

\section{[Insert Fig.8]}


Thomas model was used to predict the dynamic behavior of column performance. The linearized form of this model can be described by the following expression [55],

$\ln \left(\frac{C_{0}}{C_{t}}-1\right)=-\frac{K_{T h} q_{0} w}{Q}-K_{T h} C_{0} t$

where $\mathrm{k}_{\mathrm{Th}}\left(\mathrm{mL} \cdot \mathrm{min}^{-1} \cdot \mathrm{mg}^{-1}\right)$ is the Thomas model constant; $\mathrm{q}_{\mathrm{o}}\left(\mathrm{mg} \cdot \mathrm{g}^{-1}\right)$ is the equilibrium anion adsorbed per $g$ of the adsorbent; $C_{o}\left(m g \cdot L^{-1}\right)$ is the anion concentration; $C_{t}\left(m g \cdot L^{-1}\right)$ is the outlet concentration at time $\mathrm{t} ; \mathrm{w}(\mathrm{g})$ the mass of adsorbent, and $\mathrm{Q}\left(\mathrm{mL} \cdot \mathrm{min}^{-1}\right)$ the flow rate. The plots of $\left.\ln \left[\mathrm{C}_{\mathrm{o}} / \mathrm{C}_{\mathrm{t}}\right)-1\right]$ versus time $(\mathrm{t})$ give a straight line of slope $\left(\mathrm{k}_{\mathrm{Th}}\right)$ and intercept $\left(\mathrm{q}_{\mathrm{o}}\right)$ (Figure not shown).

The relative constants and coefficients were obtained using linear regression analysis according to Eq. (12) and the results are presented in Table 5. It can be seen that the $\mathrm{k}_{\mathrm{Th}}$ values decreases with increasing initial influent concentration. It can be attributed to the higher driving force for mass transfer. Correlation coefficient values, $\mathrm{R}^{2}$, theoretical and experimental qexp values given in Table 5 are in a good accordance with each other. Therefore, the adsorption process was fit well by the Thomas model.

\section{[Insert Table 5]}

\subsubsection{Effect of bed height}

Fig. 9 shows the breakthrough curves of different bed depths at a constant flow rate of $0.5 \mathrm{ml}$ $\min ^{-1}$. It is clear that breakthrough time $\left(\mathrm{t}_{\mathrm{b}}\right)$ and exhaustion time $\left(\mathrm{t}_{\mathrm{e}}\right)$ increased with increasing bed depth while the shape and gradient of the breakthrough curves were slightly different with the variable bed depths. The slope of breakthrough curves decreased with increasing bed depth, which resulted in a broadened mass transfer zone. The sorption data were evaluated and presented in Table 6. As seen from the Table, column adsorption capacity increased with increasing bed depth. These results can be attributed to the existence of greater number of binding sites, a higher contact time for adsorption and other processes contributing to anion removal to take place in the column. The column adsorption capacity for nitrate was higher than that for phosphate at all bed heights. The results indicate that the column uptake values obtained for nitrate and phosphate were in agreement with the batch experimental data.

\section{[Insert Fig.9]}

\section{[Insert Table 6]}

\subsubsection{Effect of initial anion concentration}

Fig. 10 shows the breakthrough curves for various initial solute concentrations of nitrate and phosphate at a flow rate of $50 \mathrm{ml} \cdot \mathrm{min}^{-1}$ and bed height of $12 \mathrm{~cm}$. It is illustrated that the adsorption process reached saturation faster and the breakthrough time $\left(\mathrm{t}_{\mathrm{b}}\right)$ decreased with increasing initial anion 
concentration (Table 7). The maximum adsorption capacity of BW400 was $90.43 \mathrm{mg} \cdot \mathrm{g}^{-1}$ and 94.08 $\mathrm{mg} \cdot \mathrm{g}^{-1}$ at $100 \mathrm{mg} \cdot \mathrm{L}^{-1}$ initial anion concentration for phosphate and nitrate anions, respectively. With increased initial concentration of anions from 100 to $200 \mathrm{mg} \cdot \mathrm{L}^{-1}$, the uptake of phosphate and nitrate adsorbed were found to increase to $107.19 \mathrm{mg} \cdot \mathrm{g}^{-1}$ and $122.36 \mathrm{mg} \cdot \mathrm{g}^{-1}$, respectively. This result may be attributed to the variation in column resistance and adsorption driving force. Higher initial influent concentration led to higher driving force for mass transfer and smaller mass transfer zone. The same trend was also observed for nitrate/BW and phosphate/BW systems (Figures not given)

\section{[Insert Fig.10]}

\section{[Insert Table 7]}

\section{Conclusions}

This study investigated the adsorption characteristics and suitability of BW and heat treated BW as potential adsorbents for the removal of phosphate and nitrate from aqueous solutions using lab-scale fixed bed column and batch techniques. The results showed that both BW and heat treated BW could be used as potential sorbents for the removal of phosphate and nitrate ions from aqueous solution. The batch study parameters, $\mathrm{pH}$ of solution, initial solution concentration, contact time, and temperature were found to be effective on the adsorption processes. The kinetic studies revealed that the adsorption process followed the pseudo-second-order kinetic model. The Langmuir isotherm provides a better fitting to isotherm than Freundlich and D-R isotherms. The maximum adsorption capacity of phosphate and nitrate was 52.5 and $63.2 \mathrm{mg}^{-1}$ at optimum $\mathrm{pH} \mathrm{3.0,} \mathrm{respectively.} \mathrm{Heat} \mathrm{treatment} \mathrm{of}$ BW increased surface area thus significantly improved the adsorption capacity. For both nitrate and phosphate anions, the adsorption was shown to be negatively affected by the increasing solution temperature. The calculated thermodynamic parameters showed the feasibility, exothermic and spontaneous nature of the adsorption of phosphate and nitrate ions onto BW and BW400. Column studies showed that the adsorption capacity of both adsorbents was increased with increasing bed depth and initial influent concentration and decreased with increasing flow rate. The continuous fixedbed column significantly increased overall removal efficiency of phosphate and nitrate ions from aqueous solution when compared to batch experiments.

\section{Acknowledgements}

The authors are grateful to Turkish Higher Educational Council for financial supports and fellowships.

\section{References}

[1] F. Haghseresht, S. Wang, D.D. Do, A noval lanthanum modified bentonite, Phoslock, for phosphate removal from wastewaters, Appl. Clay Sci., 46 (2009) 369-375. 
[2] S.N. Levine, D.W. Schindler, Can. J. Fish. Aquat. Sci. 46 (1989) 2-10.

[3] N Romano, C. Zeng, Evaluating the newly proposed protocol of incorporated in nitrate toxicity experiments at different salinities: a case study with the tiger prawn, Penaeus monodon, juveniles, Aquaculture 289 (2009) 304-309.

[4] D. Majumdar, N. Gupta, Nitrate pollution of groundwater and associated human health disorders, Ind. J. Environ. Hlth. 42 (2000) 28-39.

[5] C.H. Tate, K.F. Arnold, Health and aesthetic aspects of water quality, in: F.W. Pontius (Ed.), Water Quality and Treatment, McGraw-Hill Inc., New York, 1990, pp. 63-156.

[6] H.-F. Chiu, S.-S. Tsai, C.Y. Yang, Nitrate in drinking water and risk of death from bladder cancer: An ecological case-control study in Taiwan, J. Toxic. Environ. Hlth. A 70 (2007) $1000-1004$.

[7] V.K. Gupta, A. Nayak, Cadmium removal and recovery from aqueous solutions by novel adsorbents prepared from orange peel and $\mathrm{Fe}_{2} \mathrm{O}_{3}$ nanoparticles, Chem. Eng. J. 180 (2012) 8190.

[8] V.K. Gupta, A. Rastogi, A. Nayak, Adsorption studies on the removal of hexavalent chromium from aqueous solution using a low cost fertilizer industry waste material, J. Colloid Interface Sci. 342 (2012) 135-141.

[9] V.K..Gupta, R.Jain, S. Varshney, Removal of reactofix golden yellow 3RFN from aqueous solution using wheat husk — An agricultural waste, J. Hazard. Mater. 142 (2007) 443-448.

[10] V.K.Gupta, I.Ali, V.K. Saini, Defluoridation of wastewaters using waste carbon slurry, Water Res. 41 (2007) 3307-3316

[11] V.K. Gupta, A. Mittal, L. Kurup, J. Mittal, Adsorption of a hazardous dye, erythrosine, over hen feathers, J. Colloid Interface Sci. 304 (2006) 52-57.

[12] V.K. Gupta, A. Rastogi, A. Nayak, Biosorption of nickel onto treated alga (Oedogonium hatei): Application of isotherm and kinetic models, J. Colloid Interface Sci. 342 (2010) 533539.

[13] A. Afkhami, T. Madrakian, Z. Karimi, The effect of acid treatment of carbon cloth on the adsorption of nitrite and nitrate ions, J. Hazard. Mater. 144 (2007) 427-431.

[14] A. Bhatnagar, M. Ji, Y.H. Choi, W. Jung, S. H. Lee, S.J. Kim, G. Lee, H. Suk, H.S. Kim, B. Min, S.H. Kim, B.H. Jeon, J.W. Kang, Removal of nitrate from water by adsorption onto zinc chloride treated activated carbon, Sep. Sci. Technol. 43 (2008) 886-907.

[15] L. Zhang, Q. Zhou, J. Liua, N. Chang, L. Wan, J. Chen, Phosphate adsorption on lanthanum hydroxide-doped activated carbon fiber, Chem. Eng. J. 185- 186 (2012) 160- 167.

[16] J.Y. Liu, L. Zhang, L.H. Wan, N. Chang, C. Duan, Q. Zhou, X.L. Li, X.Z. Wang, Removal of phosphate from water by activated carbon fiber loaded with lanthanum oxide, J. Hazard. Mater. 190 (2011) 848-855. 
[17] J.Y. Liu, L.H. Wan, L. Zhang, Q. Zhou, Effect of pH, ionic strength, and temperature on the phosphate adsorption onto lanthanum-doped activated carbon fiber, J. Colloid Interface Sci. 364 (2011) 490-496.

[18] S. Chatterjee, S.H. Woo, The removal of nitrate from aqueous solutions by chitosan hydrogel beads, J. Hazard. Mater. 164 (2009) 1012-1018.

[19] S. Chatterjee, D.S. Lee, M.W. Lee, S.H. Woo, Nitrate removal from aqueous solutions by cross-linked chitosan beads conditioned with sodium bisulfate, J. Hazard. Mater. 166 (2009) $508-513$.

[20] S. Benyoucef, M. Amran, Adsorption of phosphate ions onto low cost Aleppo pine adsorbent, Desalination 275 (2011) 231-236.

[21] K. Jaafari, S. Elmaleh, J. Coma, K. Benkhouja, Equilibrium and kinetics of nitrate by protonated cross-linked chitosan, Water SA 27 (2001) 9-13.

[22] Y.A. Zheng, A.Q. Wang, Potential of phosphate ion removal using an $\mathrm{Al}^{3+}$-cross-linked chitosan-g-poly(acrylic acid)/vermiculite ionic hybrid, Adsorpt. Sci. Technol. 28 (2010) 8999.

[23] J. Daia, H. Yang, H. Yan, Y. Shangguan, Q. Zheng, R. Cheng, Phosphate adsorption from aqueous solutions by disused adsorbents: Chitosan hydrogel beads after the removal of copper (II), Chem. Eng. J. 166 (2011) 970-977.

[24] M. Aryal, M. Liakopoulou-Kyriakides, Equilibrium, kinetics and thermodynamic studies on phosphate biosorption from aqueous solutions by Fe(III)-treated Staphylococus xylosus biomass: Common ion effect, Colloids and Surfaces A: Physicochem. Eng. Aspects, 387 (2011) 43- 49.

[25] K. Wang, B. Xing, Mutual effects of cadmium and phosphate on their adsorption and desorption by goethite, Environ. Pol.127 (2004)13-20.

[26] K.G. Bhattacharyya, S.S. Gupta, Adsorption of a few heavy metals on natural and modified kaolinite and montmorillonite: a review, Adv. Colloid Interf. Sci. 140 (2008) 114-131.

[27] C.J. Mena-Duran, M.R. Sun Kou, T. Lopez, J.A. Azamar-Barrios, D.H. Aguilar, M.I. Dominguez, J.A. Odriozola, P. Quintana, Nitrate removal using natural clays modified by acid thermoactivation, Appl. Surf. Sci. 253 (2007) 5762-5766.

[28] S. Wang, Y. Peng, Natural zeolites as effective adsorbents in water and wastewater treatment, Chem. Eng. J. 156 (2010) 11-24.

[29] P. Ning, H.J. Bart, B. Li, X. Lu, Y. Zhang, Phosphate removal from wastewaterby model-La (III) zeolite adsorbents, J. Environ. Sci. 20 (2008) 670-674.

[30] M. Chabani, A. Amrane, A. Bensmaili, Kinetics of nitrates adsorption on Amberlite IRA 400 resin, Desalination, 206 (2007) 560-567.

[31] A. Ozcan, M. Sahin, A.S. Ozcan, Adsorption of nitrate ions onto sepiolite and surfactantmodified sepiolite, Adsor. Sci. Technol. 23 (2005) 323-333. 
[32] C. Namasivayam, W.H. Holl, Quaternized biomass as an anion exchanger for the removal of nitrate and other anions from water, J. Chem. Technol. Biotechnol. 80 (2005) 164-168.

[33] S. Hamoudi, R. Saad, K. Belkacemi, Adsorptive removal of phosphate and nitrate anions from aqueous solutions using ammonium-functionalized mesoporous silica, Ind. Eng. Chem. Res. 46 (2007) 8806-8812.

[34] R. Saad, S. Hamoudi, K. Belkacemi, Adsorption of phosphate and nitrate anions on ammonium-functionnalized mesoporous silicas, J. Porous Mater. 15 (2008) 315-323.

[35] E.W. Shin, J.S. Han, M. Jang, S.H. Min, J.K. Park, R.M. Rowell, Phosphate adsorptionon aluminum-impregnated mesoporous silicates: surface structure and behavior of adsorbents, Environ. Sci. Technol. 38 (2004) 912-917.

[36] Y. Wang, B.Y. Gao, W.W. Yue, Q.Y. Yue, Preparation and utilization of wheat straw anionic sorbent for the removal of nitrate from aqueous solution, J. Environ. Sci. 19 (2007) 13051310.

[37] X. Xu, B.Y. Gao, Q.Y. Yue, Q.Q. Zhong, Preparation of agricultural by-product based anion exchanger and its utilization for nitrate and phosphate removal, Biores. Techn. 101 (2010) $8558-8564$.

[38] Y. Wang, B.Y. Gao, W.W. Yue, Q.Y. Yue, Adsorption kinetics of nitrate from aqueous solutions onto modified wheat residue, Colloids Surf. A: Physicochem. Eng. Aspects, 308 (2007) $1-5$.

[39] Y. Wang, B.Y. Gao, W.W. Yue, X.M. Xu, X. Xu, Adsorption kinetics of phosphate from aqueous solutions onto modified corn residue, Environ. Sci. 29 (2008) 703-708.

[40] P. Castaldi, M. Silvetti, G. Garau, S. Deiana, Influence of the $\mathrm{pH}$ on the accumulation of phosphate by red mud (a bauxite ore processing waste), J. Hazard. Mater. 182 (2010) 266272.

[41] W. Huang, S. Wang, Z. Zhu, L. Li, X. Yao, V. Rudolph, F. Haghseresht, Phosphate removal from waste water using red mud, J. Hazard. Mater. 158 (2008) 35-42.

[42] A. Olgun, N. Atar, Removal of copper and cobalt from aqueous solution onto waste containing boron impurity, Chem. Eng. J. 167 (2011) 140-147.

[43] A. Olgun, N. Atar, Equilibrium, thermodynamic and kinetic studies for the adsorption of lead (II) and nickel (II) onto clay mixture containing boron impurity, J. Ind. Eng. Chem. 18 (2012) 1751- 1757.

[44] N. Atar, A. Olgun, S. Wang, Adsorption of cadmium (II) and zinc (II) on boron enrichment process waste in aqueous solutions: Batch and fixed-bed system studies, Chem. Eng. J. 192 (2012) 1-7.

[45] Atar N., Olgun A., Removal of acid blue 062 in aqueous solution using calcinated colemanite ore waste, J. Hazard. Mater. 146 (2007) 171-179. 
[46] A. Olgun, N. Atar, Equilibrium and kinetic adsorption study of Basic Yellow 28 and Basic Red 46 by a boron industry waste, J. Hazard. Mater. 161 (2009) 148-156.

[47] N. Atar, A. Olgun, Removal of basic and acid dyes from aqueous solutions by a waste containing boron impurity, Desalination 249 (2009) 109-115.

[48] N. Atar, S. Wang, A. Olgun, S. Liu, Adsorption of anionic dyes on boron industry waste in single and binary solutions using batch and fixed-bed systems, J. Chem. Eng. Data 56 (2011) $508-516$.

[49] S. Lagergren, Zur theorie der sogenannten adsorption gel€oster stoffe, Kungliga Svenska Vetenskapsakademiens. Handlingar 24 (1898) 1-39.

[50] Y.S. Ho, G. McKay, Kinetic models for the sorption of dye from aqueous solution by wood, Process Saf. Environ. Prot. 76 (1998) 183-191.

[51] W.J. Weber, J.C. Morris, Kinetics of adsorption on carbon from solution, J. Sanit. Eng. Div. A.S.C.E. 89 (1963) 31-59.

[52] I. Langmuir, The adsorption of gases on plane surfaces of glass, mica and platinum, J. Am. Chem. Soc. 40 (1918) 1361-1403.

[53] H. M. F. Freundlich, Uber die adsorption in Losungen, Z. Phys.Chem. 57 (1906) 385-470.

[54] M.M. Dubinin, L.V. Radushkevich, Equation of the characteristic curve of activated charcoal, Proc. Acad. Sci. USSR 55 (1947) 331.

[55] H. C. Thomas, Heterogeneous ion exchange in a flowing system, J. Am. Chem. Soc. 66 (1944) 1664-1666. 


\section{Table captions}

Table 1. Comparison of kinetic parameters for the adsorption of phosphate and nitrate onto BW and BW400

Table 2. Isotherm parameters of phosphate and nitrate adsorption on BW and BW400.

Table 3 Comparison adsorption capacity of the BW400 with other adsorbents.

Table 4.Thermodynamic Parameters of the phosphate and nitrate adsorption on BW and BW400.

Table.5 Column parameters for the effect of flow rate on the adsorption of phosphate and nitrate onto BW and BW400.

Table 6. Column parameters for the effect of bed height on the adsorption of phosphate and nitrate onto BW and BW400.

Table 7. Column parameters for the effect of initial ion concentration on the adsorption of phosphate and nitrate onto BW and BW400. 


\section{Figure captions}

Fig. 1. Effect of $\mathrm{pH}$ values on phosphate and nitrate adsorption on BW and BW400.

Fig. 2. Variation of zeta potential of BW and BW400 with $\mathrm{pH}$ value.

Fig. 3 Variation of BET surface area of BW with heat temperature.

Fig. 4 Effect of heat treatment on the adsorption capacity of BW.

Fig. 5 Effects of contact time and temperature on the adsorption of nitrate onto BW400.

Fig. 6 Effects of contact time and temperature on the adsorption of phosphate onto BW400.

Fig. 7 Langmuir isotherm model for phosphate and nitrate removal from aqueous solution on BW and BW400.

Fig. 8a Effect of flow rate for the adsorption of nitrate onto BW400.

Fig. 8b Effect of flow rate for the adsorption of phosphate onto BW400.

Fig. 9a Effect of bed height for the adsorption of nitrate onto BW400.

Fig. 9b Effect of bed height for the adsorption of phosphate onto BW400.

Fig. 10a Effect of inlet concentration for the adsorption of nitrate onto BW400.

Fig. 10b Effect of inlet concentration for the adsorption of phosphate onto BW400. 
Table 1. Comparison of kinetic parameters for the adsorption of phosphate and nitrate onto BW and BW400

\begin{tabular}{|c|c|c|c|c|c|c|c|c|c|c|c|}
\hline \multirow[t]{2}{*}{ Adsorbent } & & \multirow[t]{2}{*}{$\mathrm{T}(\mathrm{K})$} & \multicolumn{3}{|c|}{ Pseudo-first-order kinetic model } & \multicolumn{3}{|c|}{ Pseudo-second-order kinetic model } & \multicolumn{3}{|c|}{ Intraparticle diffusion model } \\
\hline & & & $\mathrm{q}_{1}(\mathrm{mg} / \mathrm{g})$ & $\mathrm{k}_{1}\left(\min ^{-1}\right)$ & $R^{2}$ & $\mathrm{q}_{2}(\mathrm{mg} / \mathrm{g})$ & $\mathrm{k}_{2}(\mathrm{~g} / \mathrm{mg} \min )$ & $R^{2}$ & $\mathrm{kp}\left(\mathrm{mg} / \mathrm{g} \min ^{1 / 2}\right)$ & $\mathrm{C}(\mathrm{mg} / \mathrm{g})$ & $R^{2}$ \\
\hline \multirow{8}{*}{ 它 } & \multirow{4}{*}{ Phosphate } & 298 & 28.20 & $4.85 \times 10^{-2}$ & 0.875 & 31.25 & $2.63 \times 10^{-3}$ & 0.999 & 1.68 & 11.73 & 0.929 \\
\hline & & 308 & 26.07 & $4.32 \times 10^{-2}$ & 0.911 & 30.77 & $2.31 \times 10^{-3}$ & 0.997 & 1.72 & 10.41 & 0.956 \\
\hline & & 318 & 26.59 & $4.30 \times 10^{-2}$ & 0.961 & 30.30 & $1.96 \times 10^{-3}$ & 0.997 & 1.85 & 8.08 & 0.947 \\
\hline & & 328 & 23.72 & $3.64 \times 10^{-2}$ & 0.967 & 29.67 & $1.67 \times 10^{-3}$ & 0.998 & 1.94 & 6.03 & 0.950 \\
\hline & \multirow{4}{*}{ Nitrate } & 298 & 48.43 & $3.32 \times 10^{-2}$ & 0.932 & 57.14 & $5.51 \times 10^{-4}$ & 0.998 & 4.02 & 4.23 & 0.966 \\
\hline & & 308 & 40.09 & $2.99 \times 10^{-2}$ & 0.989 & 52.63 & $5.85 \times 10^{-4}$ & 0.999 & 3.71 & 3.57 & 0.964 \\
\hline & & 318 & 31.47 & $3.73 \times 10^{-2}$ & 0.991 & 38.46 & $1.14 \times 10^{-3}$ & 0.999 & 2.62 & 6.14 & 0.937 \\
\hline & & 328 & 28.96 & $4.26 \times 10^{-2}$ & 0.990 & 33.78 & $1.51 \times 10^{-3}$ & 0.997 & 2.26 & 6.67 & 0.905 \\
\hline \multirow{8}{*}{$\begin{array}{l}\stackrel{8}{8} \\
\stackrel{+}{+} \\
\text { 3. }\end{array}$} & \multirow{4}{*}{ Phosphate } & 298 & 52.57 & $6.51 \times 10^{-2}$ & 0.854 & 57.14 & $2.16 \times 10^{-3}$ & 0.998 & 2.86 & 27.19 & 0.959 \\
\hline & & 308 & 52.50 & $6.20 \times 10^{-2}$ & 0.921 & 56.82 & $1.79 \times 10^{-3}$ & 0.999 & 3.22 & 22.81 & 0.957 \\
\hline & & 318 & 54.95 & $6.49 \times 10^{-2}$ & 0.932 & 55.25 & $1.73 \times 10^{-3}$ & 0.999 & 3.37 & 20.10 & 0.917 \\
\hline & & 328 & 57.25 & $6.42 \times 10^{-2}$ & 0.920 & 53.76 & $1.50 \times 10^{-3}$ & 0.999 & 3.51 & 16.55 & 0.925 \\
\hline & \multirow{4}{*}{ Nitrate } & 298 & 52.54 & $4.42 \times 10^{-2}$ & 0.928 & 69.93 & $1.29 \times 10^{-3}$ & 0.999 & 3.62 & 28.25 & 0.926 \\
\hline & & 308 & 52.10 & $4.63 \times 10^{-2}$ & 0.968 & 66.67 & $1.26 \times 10^{-3}$ & 0.999 & 3.64 & 24.84 & 0.914 \\
\hline & & 318 & 49.31 & $5.37 \times 10^{-2}$ & 0.979 & 60.98 & $1.58 \times 10^{-3}$ & 0.998 & 3.25 & 24.50 & 0.875 \\
\hline & & 328 & 50.73 & $4.95 \times 10^{-2}$ & 0.968 & 58.82 & $1.42 \times 10^{-3}$ & 0.999 & 3.28 & 21.51 & 0.901 \\
\hline
\end{tabular}


Table 2. Isotherm parameters of phosphate and nitrate adsorption on BW and BW400.

\begin{tabular}{|c|c|c|c|c|c|c|c|c|c|c|c|}
\hline \multirow[b]{2}{*}{ Adsorbent } & & \multicolumn{3}{|c|}{ Langmuir isotherm } & \multicolumn{3}{|c|}{ Freundlich isotherm } & \multicolumn{4}{|c|}{ D-R isotherm } \\
\hline & & $q_{\max }(\mathrm{mol} / \mathrm{g})$ & $K_{L}(\mathrm{~L} / \mathrm{mol})$ & $R^{2}$ & $K_{F}(\mathrm{~mol} / \mathrm{g})$ & $1 / \mathrm{n}$ & $R^{2}$ & $q_{\max }(\mathrm{mol} / \mathrm{g})$ & $\beta\left(\mathrm{mol}^{2} / \mathrm{J}^{2}\right)$ & $R^{2}$ & $\mathrm{E}(\mathrm{kJ} / \mathrm{mol})$ \\
\hline \multirow{2}{*}{ BW } & Phosphate & $3.49 \times 10^{-4}$ & $1.06 \times 10^{4}$ & 0.998 & $6.43 \times 10^{-5}$ & 0.40 & 0.938 & $1.16 \times 10^{-3}$ & $3.76 \times 10^{-9}$ & 0.959 & 11.53 \\
\hline & Nitrate & $7.88 \times 10^{-4}$ & $8.18 \times 10^{3}$ & 0.998 & $1.25 \times 10^{-4}$ & 0.46 & 0.974 & $2.84 \times 10^{-3}$ & $4.33 \times 10^{-9}$ & 0.988 & 10.75 \\
\hline \multirow{2}{*}{ BW400 } & Phosphate & $6.12 \times 10^{-4}$ & $2.36 \times 10^{4}$ & 0.998 & $1.26 \times 10^{-4}$ & 0.55 & 0.989 & $4.34 \times 10^{-3}$ & $4.42 \times 10^{-9}$ & 0.995 & 10.64 \\
\hline & Nitrate & $1.01 \times 10^{-3}$ & $5.61 \times 10^{4}$ & 0.999 & $3.86 \times 10^{-4}$ & 0.36 & 0.916 & $3.60 \times 10^{-3}$ & $2.95 \times 10^{-9}$ & 0.947 & 13.02 \\
\hline
\end{tabular}


Table 3 Comparison of phosphate and nitrate ions adsorption on various adsorbents

\begin{tabular}{llll}
\hline Adsorbent & Phosphate $\left(\mathrm{mg} \mathrm{g}^{-1}\right)$ & Nitrate $\left(\mathrm{mg} \mathrm{g}^{-1}\right)$ & Reference \\
This study (batch studies) & 52.51 & 63.16 & \\
This study (Column studies) & 107.19 & 122.36 & {$[29]$} \\
Activated alumina & 53.7 & - & {$[33]$} \\
Corn stalk based resin & 40.48 & - & {$[31]$} \\
Wheat straw & 45.7 & 52.8 & {$[23]$} \\
Modified zeolite & 24.6 & 45.6 & {$[24]$} \\
Amberlite IRA 400 & - & 65.36 & {$[11]$} \\
Lanthanum-doped activated & 9.41 & - & \\
carbon fiber (ACF-La). & & & \\
$\begin{array}{l}\text { Cross-linking with } \\
\text { epichlorohydrin (ECH) }\end{array}$ & - & 104.0 & \\
\hline
\end{tabular}


Table.4 Thermodynamic Parameters of the phosphate and nitrate adsorption on BW and BW400.

\begin{tabular}{lllllllll}
\hline Adsorbent & & \multicolumn{3}{l}{$\Delta G^{o}(\mathrm{kj} / \mathrm{mol})$} & & \multirow{2}{*}{$\Delta H^{o}(\mathrm{~kJ} / \mathrm{mol})$} & $\Delta S^{o}(\mathrm{~J} / \mathrm{mol} \mathrm{K})$ & $R^{2}$ \\
\cline { 3 - 6 } & & $298 \mathrm{~K}$ & $308 \mathrm{~K}$ & $318 \mathrm{~K}$ & $328 \mathrm{~K}$ & & & \\
\hline \multirow{2}{*}{ BW } & Phosphate & -0.62 & -0.57 & -0.19 & 0.07 & -7.86 & -24.07 & 0.935 \\
& Nitrate & -1.24 & -0.54 & 0.62 & 1.11 & -25.77 & -82.29 & 0.979 \\
& & & & & & & & \\
\multirow{2}{*}{ BW400 } & Phosphate & -4.77 & -4.39 & -3.97 & -3.45 & -17.81 & -43.68 & 0.997 \\
& Nitrate & -5.51 & -4.38 & -3.40 & -3.02 & -30.82 & -89.18 & 0.972 \\
\hline
\end{tabular}


Table.5 Column parameters for the effect of flow rate on the adsorption of phosphate and nitrate onto BW and BW400.

\begin{tabular}{|c|c|c|c|c|c|c|c|c|}
\hline \multirow[b]{2}{*}{ Adsorbent } & & \multirow[b]{2}{*}{$\begin{array}{l}\text { Flow rate } \\
(\mathrm{mL} / \mathrm{min})\end{array}$} & \multirow[b]{2}{*}{$\begin{array}{c}\mathrm{q}_{\mathrm{e}} \\
(\mathrm{mg} / \mathrm{g})\end{array}$} & \multirow[b]{2}{*}{$\begin{array}{l}t_{b} \\
(h)\end{array}$} & \multirow[b]{2}{*}{$\begin{array}{l}t_{e} \\
(h)\end{array}$} & \multicolumn{3}{|c|}{ Thomas model } \\
\hline & & & & & & $\begin{array}{l}\mathrm{k}_{\mathrm{Th}} \times 10^{3} \\
(\mathrm{~L} / \mathrm{mg} \mathrm{h})\end{array}$ & $\begin{array}{l}q_{o} \\
(\mathrm{mg} / \mathrm{g})\end{array}$ & $R^{2}$ \\
\hline \multirow{6}{*}{ 崩 } & & 0.5 & 85.30 & 15.8 & 68.4 & 3.78 & 87.15 & 0.994 \\
\hline & Phosphate & 1.0 & 79.10 & 9.6 & 52.4 & 3.95 & 80.43 & 0.985 \\
\hline & & 1.5 & 75.03 & 3.4 & 39.6 & 4.22 & 74.20 & 0.987 \\
\hline & & 0.5 & 89.64 & 20.4 & 73.6 & 2.10 & 90.68 & 0.985 \\
\hline & Nitrate & 1.0 & 82.21 & 10.9 & 65.3 & 3.42 & 85.79 & 0.986 \\
\hline & & 1.5 & 78.47 & 4.6 & 54.5 & 4.15 & 78.02 & 0.978 \\
\hline \multirow{6}{*}{ 文 } & & 0.5 & 90.43 & 22.3 & 75.4 & 3.34 & 88.19 & 0.940 \\
\hline & Phosphate & 1.0 & 86.70 & 16.3 & 70.2 & 3.69 & 84.95 & 0.989 \\
\hline & & 1.5 & 81.06 & 9.2 & 51.4 & 3.93 & 79.03 & 0.980 \\
\hline & & 0.5 & 94.08 & 25.3 & 82.1 & 1.85 & 96.19 & 0.985 \\
\hline & Nitrate & 1.0 & 89.65 & 13.4 & 75.5 & 3.39 & 88.30 & 0.964 \\
\hline & & 1.5 & 85.42 & 7.3 & 60.2 & 3.77 & 83.11 & 0.982 \\
\hline
\end{tabular}


Table 6. Column parameters for the effect of bed height on the adsorption of phosphate and nitrate onto BW and BW400.

\begin{tabular}{|c|c|c|c|c|c|c|c|c|}
\hline \multirow[b]{2}{*}{ Adsorbent } & & \multirow[b]{2}{*}{$\begin{array}{l}\text { Bed } \\
\text { height } \\
(\mathrm{cm})\end{array}$} & \multirow[b]{2}{*}{$\begin{array}{c}\mathrm{q}_{\mathrm{e}} \\
(\mathrm{mg} / \mathrm{g})\end{array}$} & \multirow[b]{2}{*}{$\begin{array}{r}t_{b} \\
(h)\end{array}$} & \multirow[b]{2}{*}{$\begin{array}{r}t_{e} \\
(h)\end{array}$} & \multicolumn{3}{|c|}{ Thomas Model } \\
\hline & & & & & & $\begin{array}{l}\mathrm{k}_{\mathrm{Th}} \times 10^{3} \\
(\mathrm{~L} / \mathrm{mg} \mathrm{h})\end{array}$ & $\begin{array}{c}\mathrm{q}_{\mathrm{o}} \\
(\mathrm{mg} / \mathrm{g})\end{array}$ & $R^{2}$ \\
\hline \multirow{6}{*}{ 方 } & & 6 & 71.09 & 2.6 & 30.3 & 6.03 & 69.86 & 0.961 \\
\hline & Phosphate & 9 & 79.62 & 6.5 & 47.4 & 5.41 & 80.03 & 0.982 \\
\hline & & 12 & 85.30 & 15.8 & 68.4 & 3.78 & 87.15 & 0.994 \\
\hline & & 6 & 73.81 & 4.6 & 46.4 & 5.94 & 70.57 & 0.968 \\
\hline & Nitrate & 9 & 81.76 & 7.2 & 61.2 & 4.02 & 82.20 & 0.983 \\
\hline & & 12 & 89.64 & 20.4 & 73.6 & 2.10 & 90.68 & 0.985 \\
\hline \multirow{6}{*}{ 菿 } & & 6 & 77.42 & 3.4 & 43.1 & 5.69 & 79.04 & 0.952 \\
\hline & Phosphate & 9 & 83.79 & 14.4 & 62.3 & 4.26 & 82.71 & 0.937 \\
\hline & & 12 & 90.43 & 22.3 & 75.4 & 3.34 & 88.19 & 0.940 \\
\hline & & 6 & 79.94 & 8.5 & 59.3 & 4.57 & 82.21 & 0.989 \\
\hline & Nitrate & 9 & 87.16 & 14.5 & 73.3 & 3.02 & 85.95 & 0.975 \\
\hline & & 12 & 94.08 & 25.3 & 82.1 & 1.85 & 96.19 & 0.985 \\
\hline
\end{tabular}


Table 7 Column parameters for the effect of initial ion concentration on the adsorption of phosphate and nitrate onto BW and BW400.

\begin{tabular}{|c|c|c|c|c|c|c|c|c|}
\hline \multirow[b]{2}{*}{ Adsorbent } & & \multirow{2}{*}{$\begin{array}{c}\mathrm{C}_{\mathrm{o}} \\
(\mathrm{mg} / \mathrm{L})\end{array}$} & \multirow[b]{2}{*}{$\begin{array}{c}q_{e} \\
(\mathrm{mg} / \mathrm{g})\end{array}$} & \multirow[b]{2}{*}{$\begin{array}{r}t_{b} \\
\text { (h) }\end{array}$} & \multirow[b]{2}{*}{$\begin{array}{r}t_{e} \\
(\mathrm{~h})\end{array}$} & \multicolumn{3}{|c|}{ Thomas Model } \\
\hline & & & & & & $\begin{array}{c}k_{T h} \times 10^{3} \\
(\mathrm{~L} / \mathrm{mg} \mathrm{h})\end{array}$ & $\begin{array}{c}q_{o} \\
(\mathrm{mg} / \mathrm{g})\end{array}$ & $R^{2}$ \\
\hline \multirow{6}{*}{ 总 } & \multirow{3}{*}{ Phosphate } & 100 & 85.30 & 15.8 & 68.4 & 3.78 & 87.15 & 0.994 \\
\hline & & 150 & 89.29 & 6.4 & 46.5 & 2.69 & 92.20 & 0.977 \\
\hline & & 200 & 96.13 & 4.5 & 41.2 & 2.05 & 94.81 & 0.969 \\
\hline & \multirow{3}{*}{ Nitrate } & 100 & 89.64 & 20.4 & 73.6 & 2.10 & 90.68 & 0.985 \\
\hline & & 150 & 95.06 & 10.2 & 67.3 & 1.92 & 96.33 & 0.969 \\
\hline & & 200 & 102.35 & 6.5 & 61.1 & 1.35 & 105.21 & 0.960 \\
\hline \multirow{6}{*}{ 字 } & \multirow{3}{*}{ Phosphate } & 100 & 90.43 & 22.3 & 75.4 & 3.34 & 88.19 & 0.940 \\
\hline & & 150 & 96.02 & 10.4 & 66.7 & 2.41 & 99.21 & 0.979 \\
\hline & & 200 & 107.19 & 7.3 & 46.8 & 1.27 & 108.35 & 0.953 \\
\hline & \multirow{3}{*}{ Nitrate } & 100 & 94.08 & 25.3 & 82.1 & 1.85 & 96.19 & 0.985 \\
\hline & & 150 & 109.73 & 13.4 & 79.3 & 1.16 & 106.03 & 0.978 \\
\hline & & 200 & 122.36 & 8.5 & 67.8 & 1.03 & 123.38 & 0.941 \\
\hline
\end{tabular}


Figures

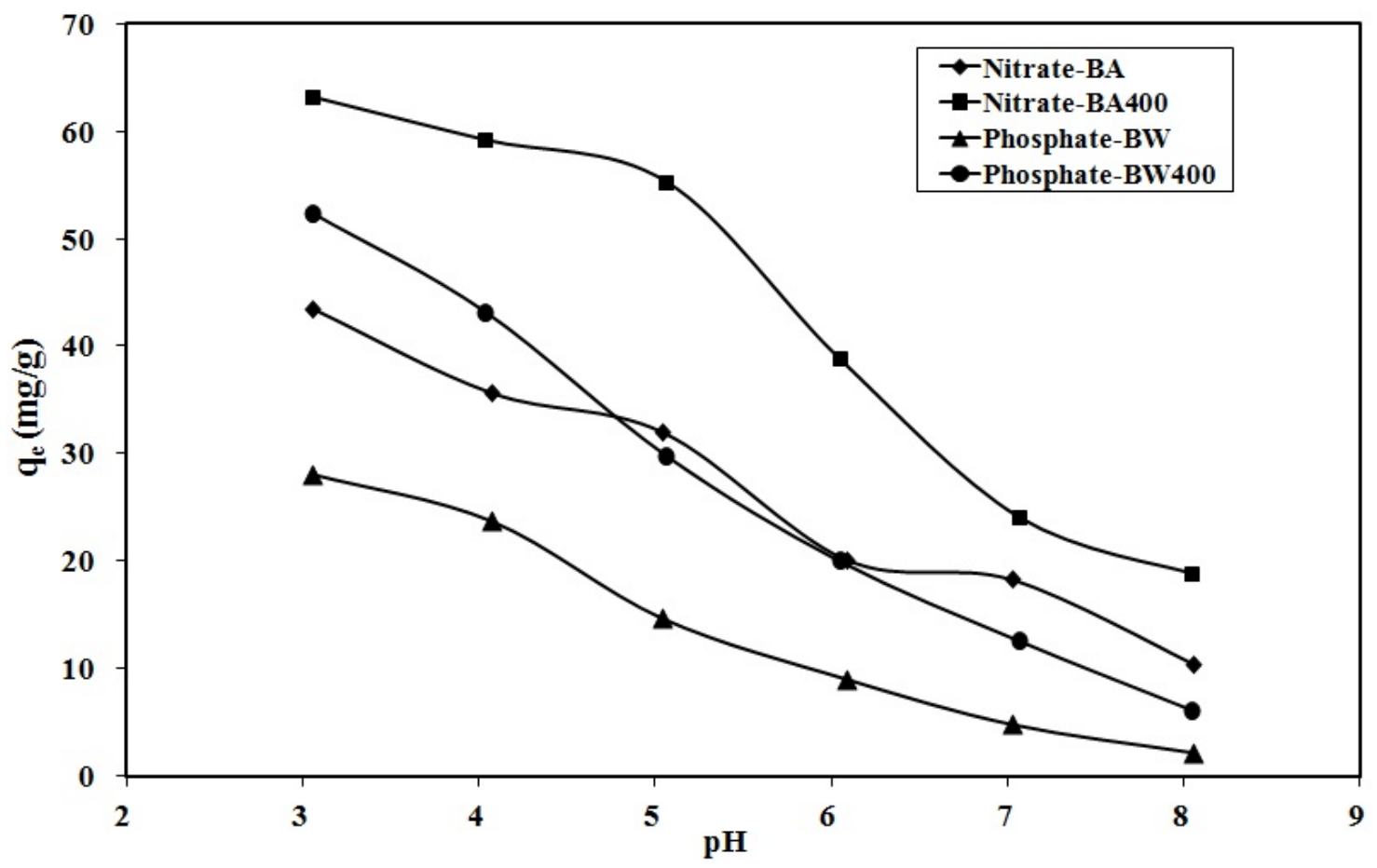

Fig.1 Effect of pH on phosphate and nitrate adsorption on BW and BW400. 


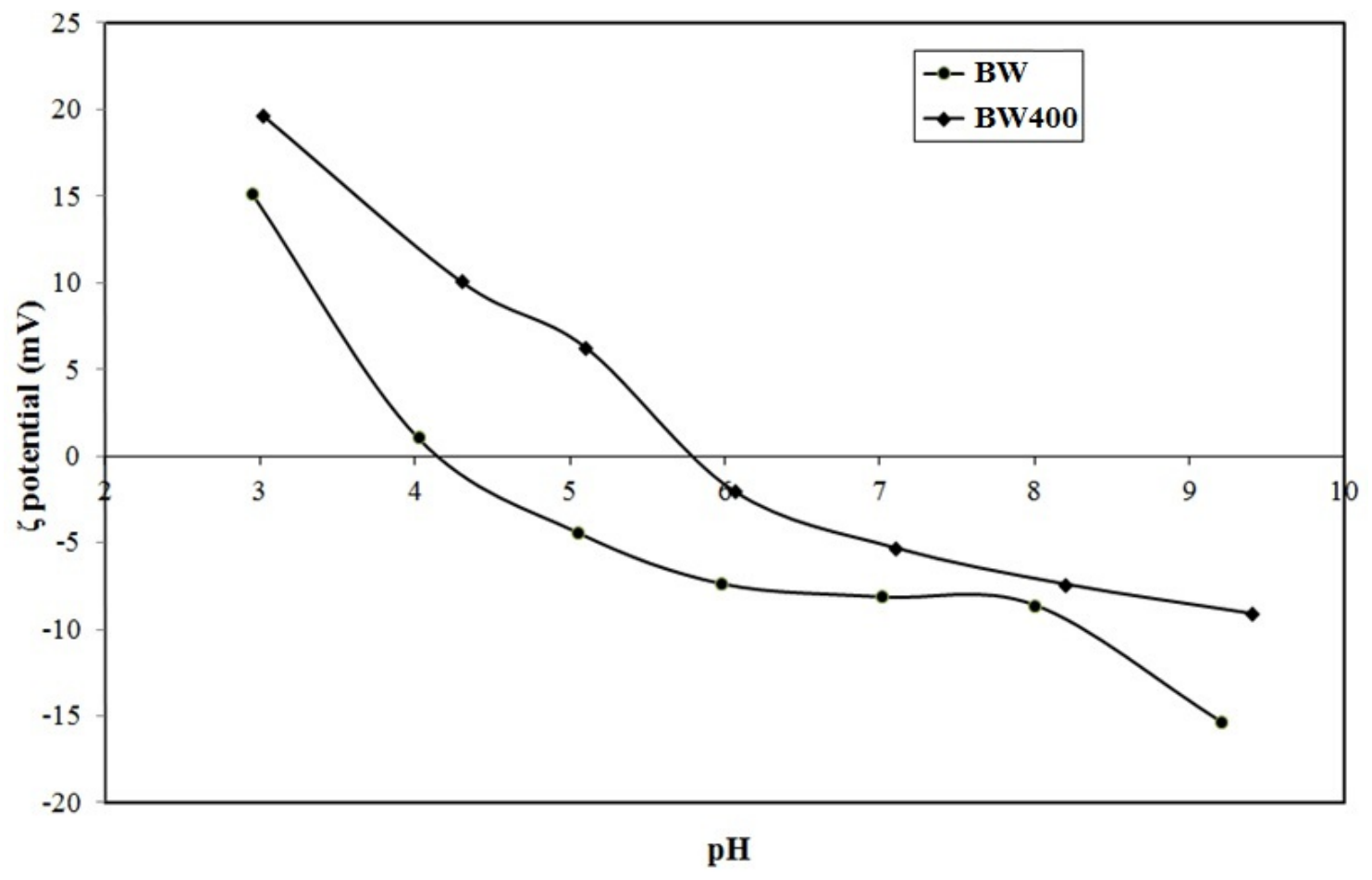

Fig.2 Variation of zeta potential of BW and BW400 with pH. 


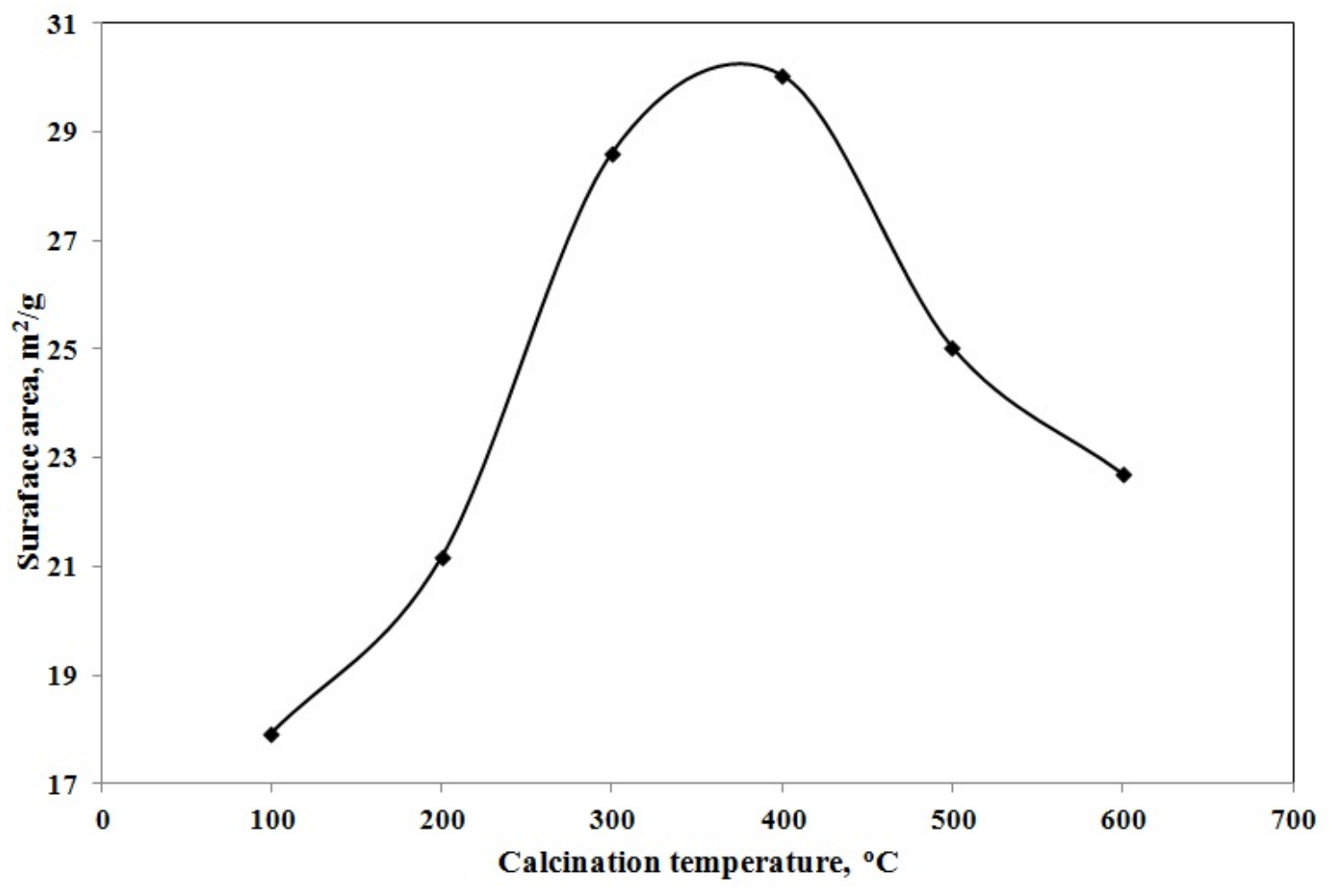

Fig.3 Variation of BET surface area of BW with heat temperature. 


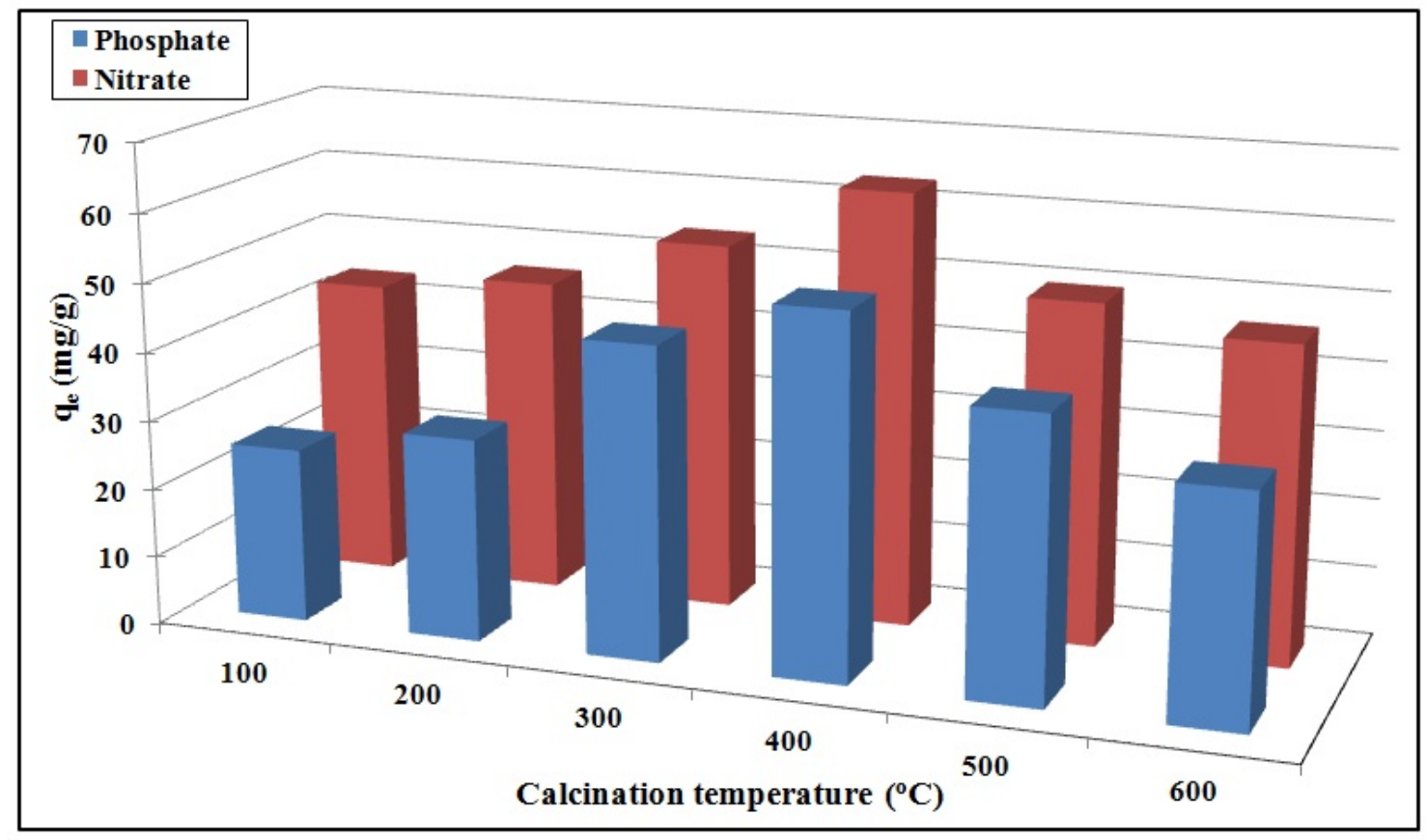

Fig.4 Effect of heat treatment on the adsorption capacity of BW. 


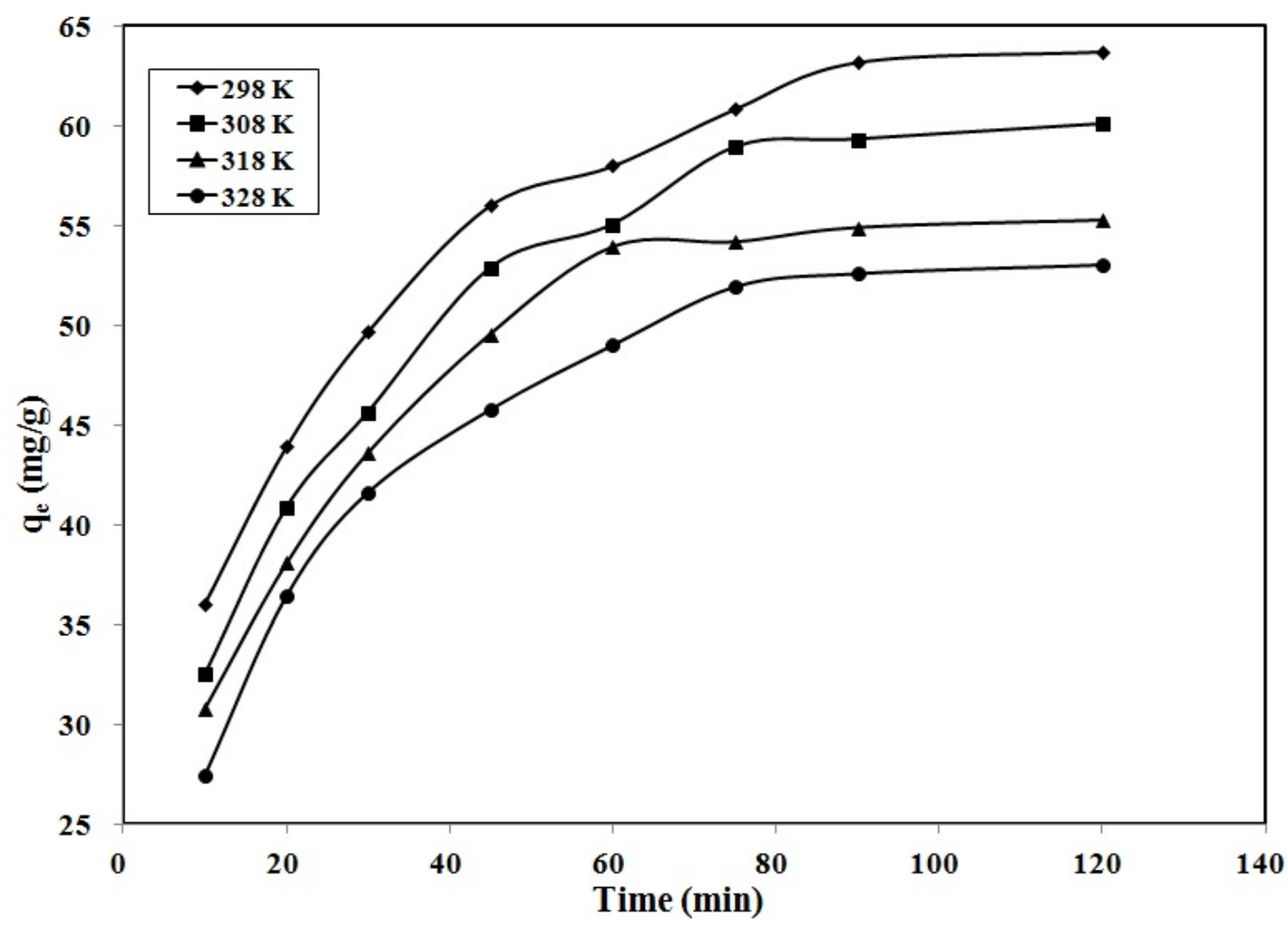

Fig. 5 Effect of contact time and temperature on the adsorption of nitrate onto BW400. 


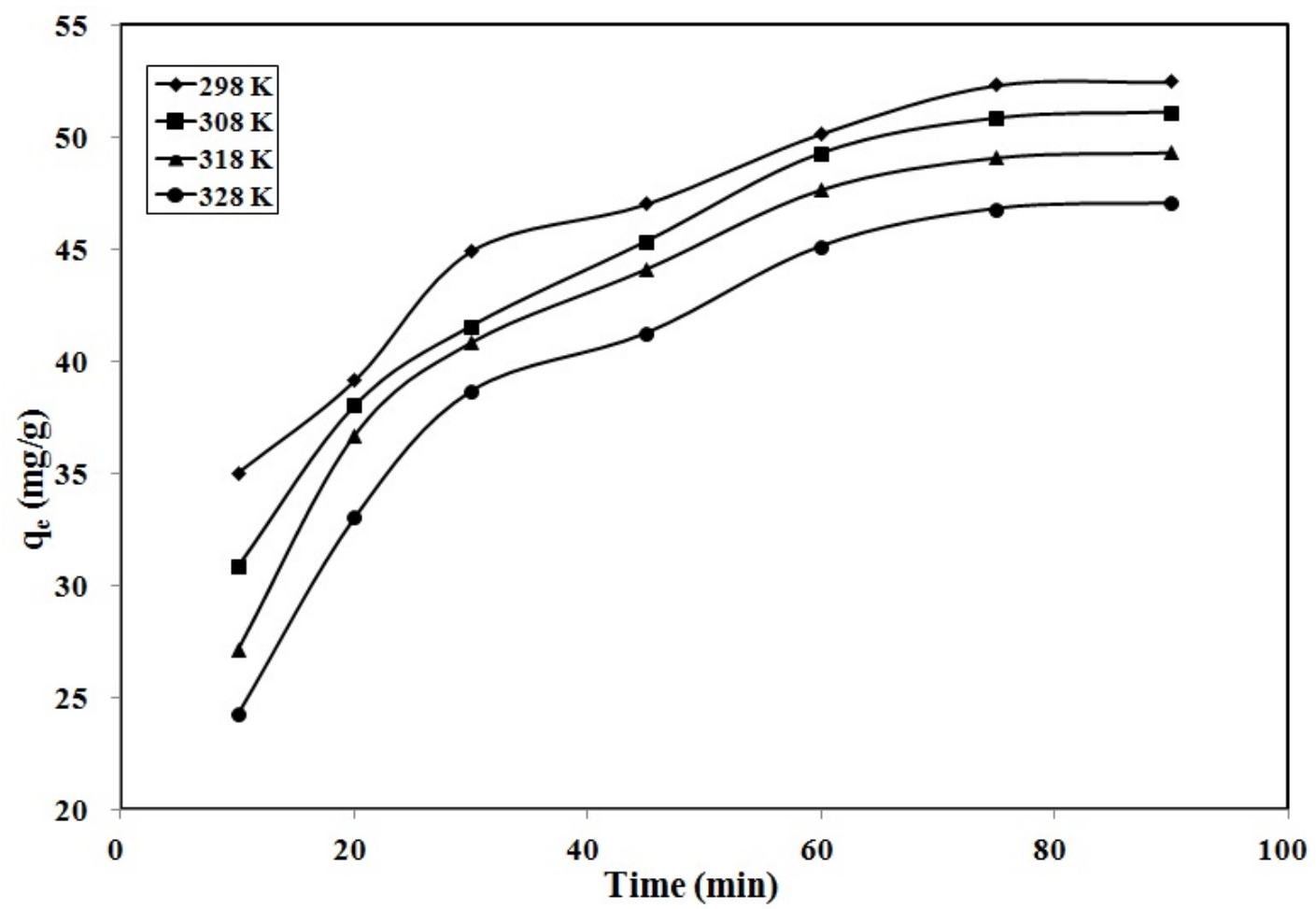

Fig.6 Effect of contact time and temperature on the adsorption of phosphate onto BW400. 


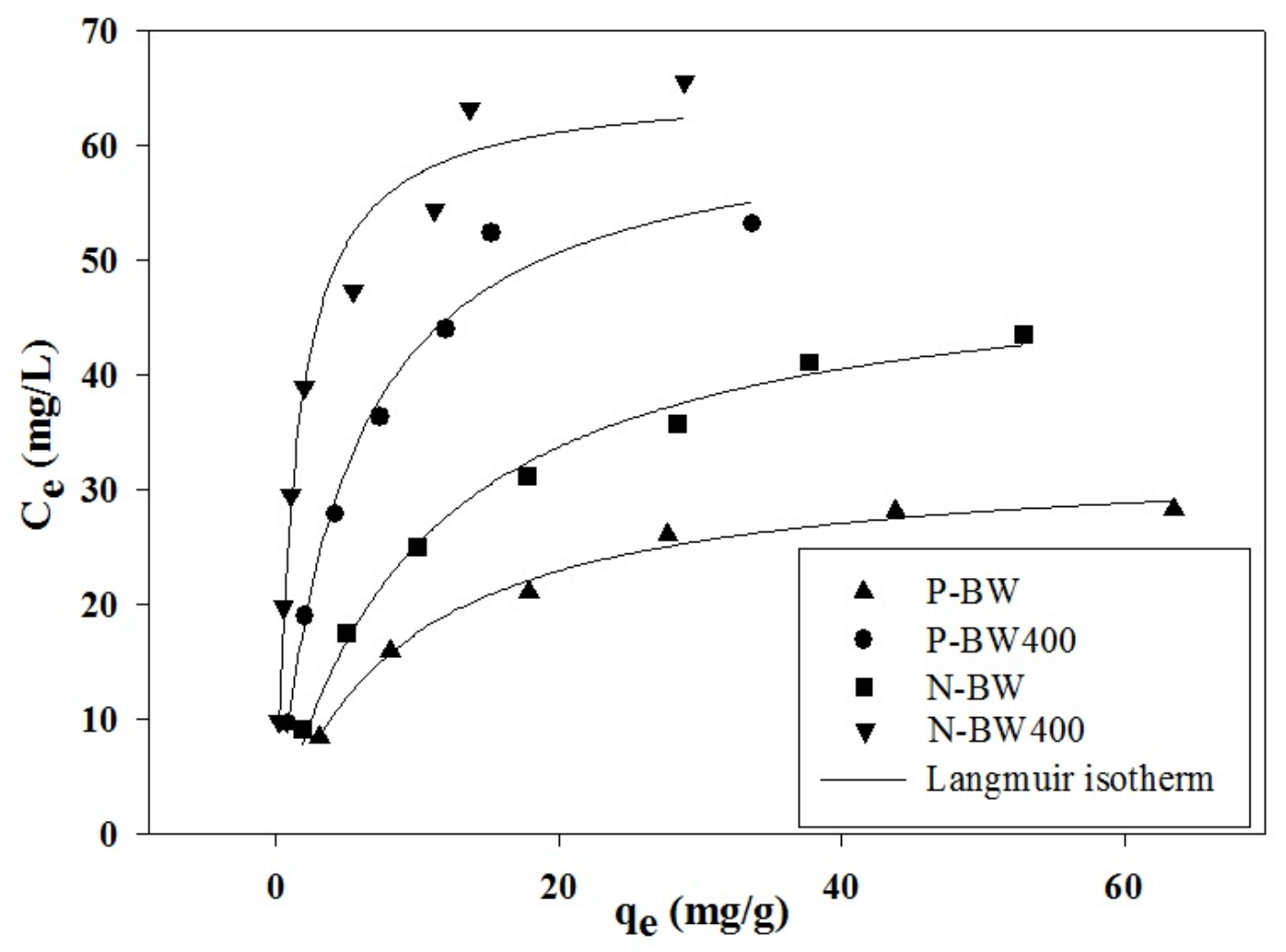

Fig.7 Langmuir isotherm model for phosphate and nitrate removal from aqueous solution on BW and BW400. 


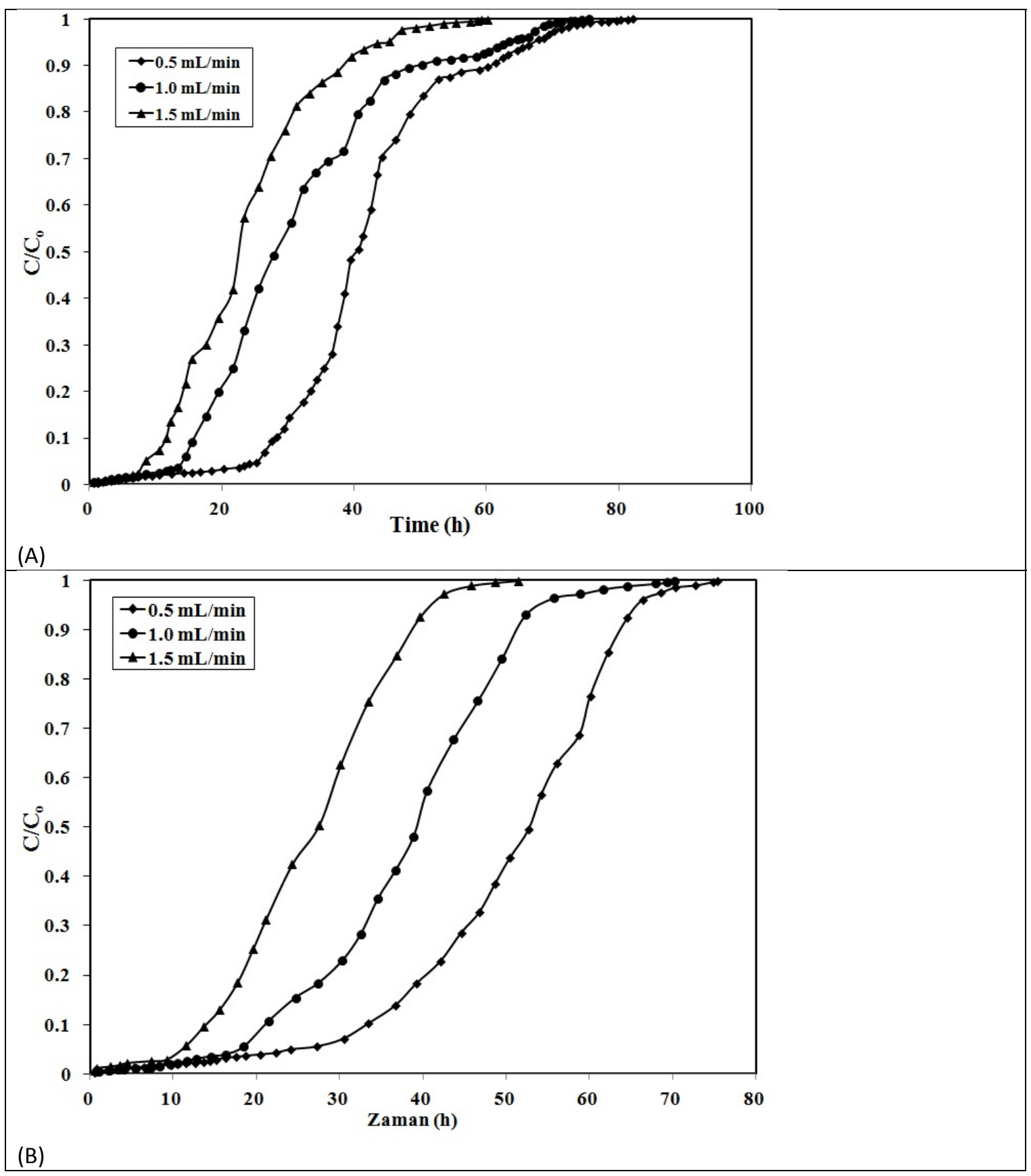

Fig.8 Effect of flow rate for the adsorption of nitrate (A) and phosphate (B) onto BW400. 


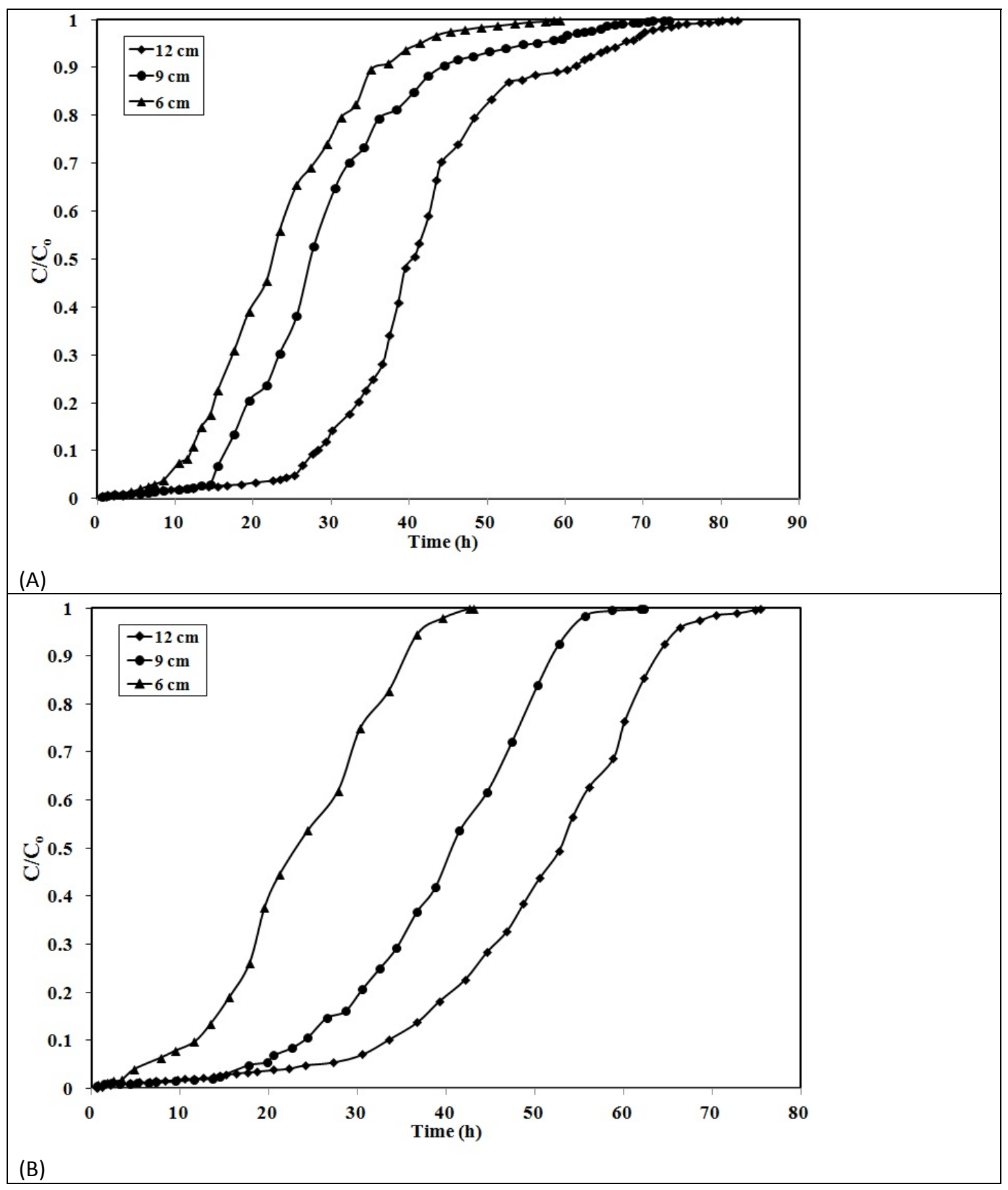

Fig.9 Effect of bed height for the adsorption of nitrate (A) and phosphate (B) onto BW400. 


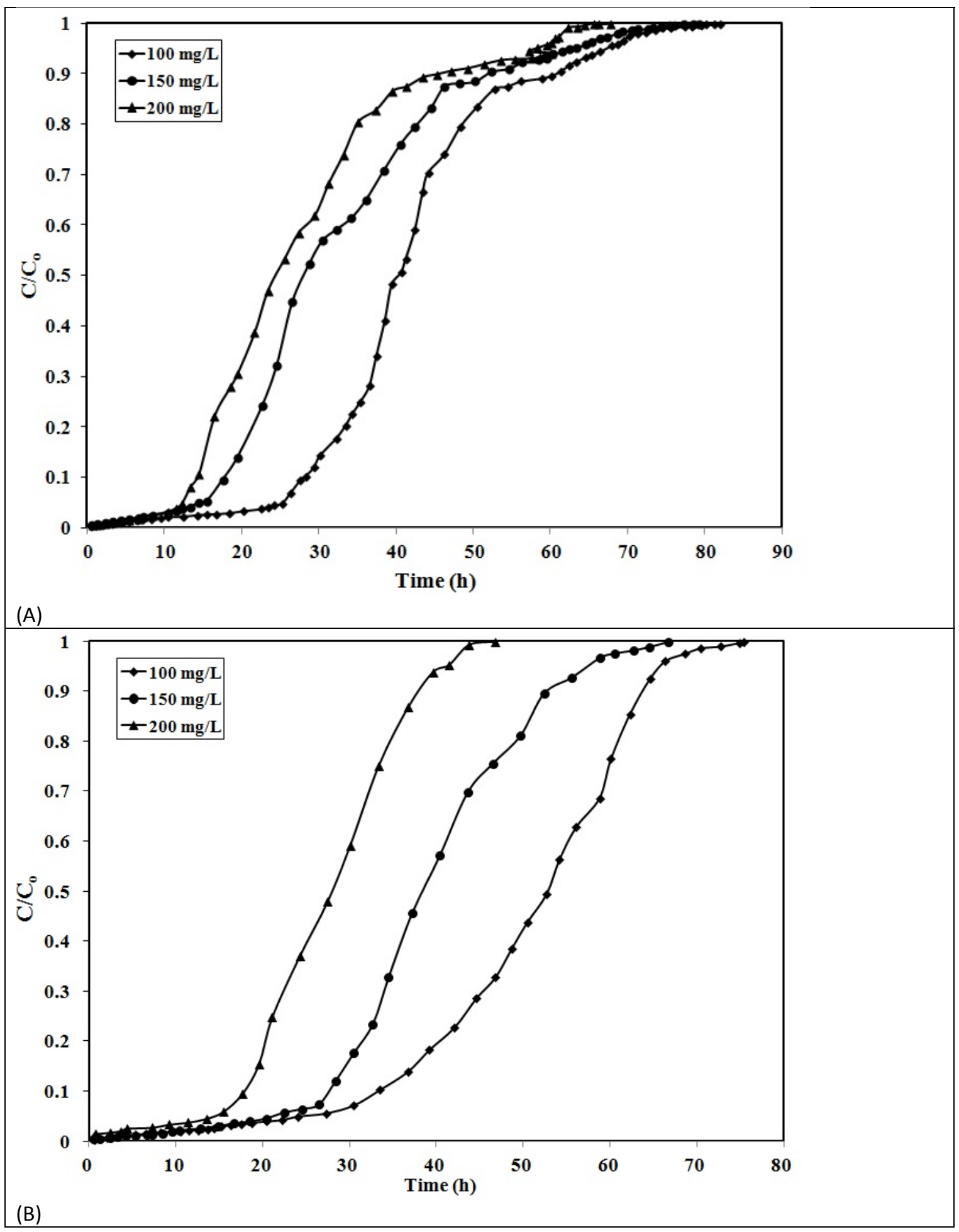

Fig.10 Effect of inlet concentration for the adsorption of nitrate (A) and phosphate (B) onto BW400. 